\title{
Sizing the government
}

\author{
Kristof De Witte · Wim Moesen
}

Received: 2 January 2008 / Accepted: 6 October 2009 / Published online: 23 October 2009

(c) The Author(s) 2009. This article is published with open access at Springerlink.com

\begin{abstract}
Is there such a thing as an optimal government size? We investigate the so-called Armey curve, which claims an inverted U-shaped relationship between government size and economic performance, using non-parametric Data Envelopment Analysis (DEA). The DEA scores are linked to control variables, such as initial per capita income, openness, population density, urbanization, country size and family size. For 23 OECD-countries we estimate the country specific efficiency scores, which reveal the extent to which a country uses excess public resources to achieve the observed growth rate of GDP.
\end{abstract}

Keywords Data envelopment analysis · Government size $\cdot$ Public sector performance · Armey-curve

JEL Classification $\mathrm{H} 10 \cdot \mathrm{H} 21 \cdot \mathrm{H} 31$

\section{Introduction}

During the second half of the last century, government involvement in OECD-countries expanded rapidly. Whereas the size of the tax burden (i.e., the ratio of tax revenue to GDP) was $24.7 \%$ in 1960, the tax burden reached an average of $36.3 \%$ in 2003. Many theories for the growth of government have been offered. Wagner's law (1877) states that the demand for governmental services has an income elasticity in excess of one. Baumol (1967) points to the unbalanced growth between the private and public sectors, Niskanen (1971) bureaucratic expansionism. Other theories mention interest-group lobbying, fiscal illusion

K. De Witte $(\varangle) \cdot$ W. Moesen

Center for Economic Studies, Katholieke Universiteit Leuven (KUL), Naamsestraat 69, 3000 Leuven, Belgium

e-mail: kristof.dewitte@econ.kuleuven.be

K. De Witte

Top Institute for Evidence Based Education Research, Maastricht University, Tongersestraat 55, 6200 MD Maastricht, The Netherlands 
Fig. 1 Tax burden 1962-2003
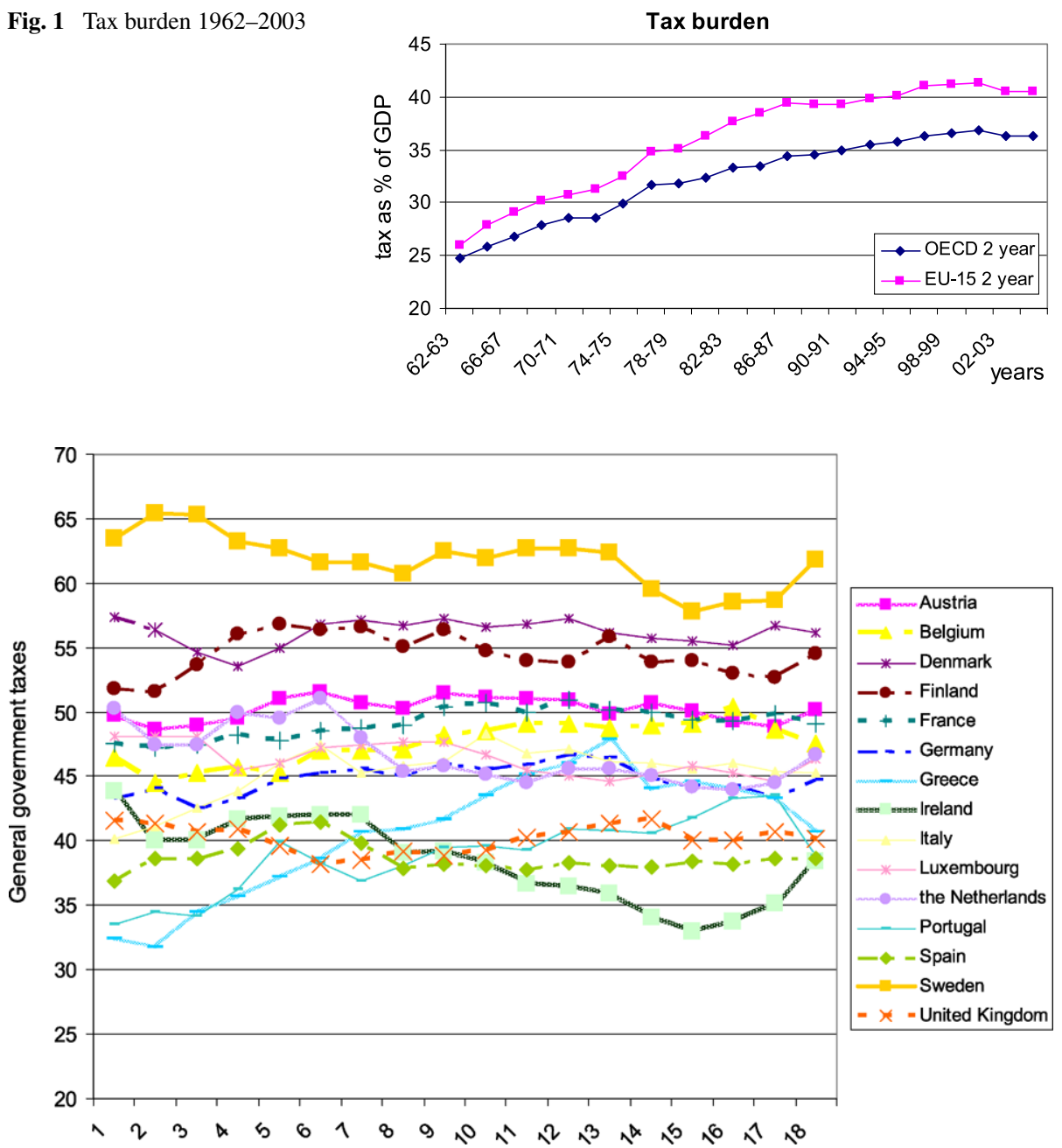

Fig. 2 Tax burden for some OECD countries

or public-employee bloc voting (for an overview see, e.g., Lybeck and Henrekson 1988; Meltzer and Richard 1983).

These theories have in common that government expansion is inherent and continuous. Although it has been argued by Higgs (1987) that due to the ratchet effect the size of government increases permanently, we observe for a sample of 23 OECD countries that from the end of the 1990s on, government involvement measured by the general tax burden slowed down and even decreased. We illustrate this in Fig. 1 where we measure the tax burden for OECD and EU-15 countries by taking two-year intervals. Focusing on the last 16 years, we present the tax burden for the 23 OECD countries in Fig. 2.

This paper follows the stream of economists which insists on downsizing government, although this is an intricate issue as the civil servants themselves have many political powers (Buchanan and Tullock 1977). In Sect. 1, we explain the arguments for downsizing the government originating in the so-called 'Armey curve' (Armey 1995). The conceptual starting 
point is a society without a government. The absence of government allows lawlessness, insecurity and instability. Even a small government could advance welfare by introducing the protection of property rights and the rule of law. But the richer society gets, the more government gets involved (Slemrod et al. 1995). The median voter prefers state-of-the-art health care, education and pension systems. As the scope of the government grows, so do the tax burden and public expenditures. Public choice theory predicts that governments will expand in size beyond its efficient level: higher public expenditures result in a lower GDP growth. Advocates of the Armey curve try to estimate the efficient level of government involvement. They obtain optimal values which are lower than the current observations.

The parametric regressions applied to estimate the optimal government size face some drawbacks which are circumvented by the non-parametric estimation in Sect. 2. Using Data Envelopment Analysis (DEA), we develop an alternative approach to determining the optimal size of the government. By applying an input-oriented model (i.e., minimization of the inputs for a given output level) on a sample of 23 OECD countries, we benchmark governments by comparing GDP growth relative to their tax burdens. In a first stage analysis, we investigate the variables as proposed by Armey (1995). We measure the size of the government by overall government spending (general government outlays). These expenditures include the spendings from the central, state and local government as well as spendings by the social security system (cfr. Gupta et al. 2001). Other measures of government size are also popular. Meltzer and Richard (1981) use the share of income redistributed by government as a measure of relative size. Katsimi (1998) defines the size of the public sector as the ratio of public to total employment. Others use the total tax level or the share of government consumption in total consumption. As these measures of government size are strongly correlated (e.g., correlation of 0.88 between public spending and the overall taxation level), our results remain robust for related measures.

In a second stage, we correct the first stage gross efficiency measures. As a first correction variable, we develop the idea of the anorexia family. Countries with lean family sizes prefer greater government involvement, since the public sector takes over several concerns which used to be handled within the family. Family size is considered as an implicit revelation of the preference for the extent of government involvement. Other correction factors are openness of the economy (Roderik 1996), initial GDP per capita to capture the catching up effect (Wagner 1877) and the income of the median voter, urbanization, country size (proxied by the total population), population density and the capital stock (a proxy for the physical capital stock).

In methodological terms, this paper develops a simple procedure to correct the DEA efficiency scores for environmental characteristics by using the residuals of Tobit regressions. We extend the procedure as suggested by Gasparini and Ramos (2003) to a more generous correction mechanism. The optimal size of the public sector is computed as the actual size times the adjusted net efficiency score. We do not consider the influences of outliers nor measurement errors. From the outset, it should be emphasized that our approach offers only a partial analysis. As such, we do not investigate the crucial issue of equity, i.e., the interpersonal redistribution of opportunities, income and wealth. Furthermore, in the context of political economy, the many dimensions of 'eudemonia' (good life and happiness) are not covered except for the contribution from real growth.

Our results show that on average and relative to the estimated optimum government size, the public sectors of the 23 OECD countries which constitute our sample should decrease by 3.74 percentage points to reach an overall tax burden of $41.22 \%$ of GDP. The Italian public sector, followed by the Swedish, would be prone to the largest decreases of, respectively, 10.24 and 7.88 percentage points. Public spending in New Zealand appears to be too low and could thus increase. 


\section{Is there an optimal government size?}

\subsection{The Armey curve}

The search for an optimal size of government has been popularized by Armey (1995). The so-called 'Armey curve', which is represented in Fig. 3, describes the relationship between the growth of the economy and the size of the public sector (proxied by the tax burden). If the government has no resources (i.e., zero taxation level), the growth rate of the economy corresponds to $G_{0}$. In a world without rule of law, private agents have to protect their own property rights. The establishment of a government skims some income, but creates a higher growth rate by introducing the provision of public goods and services which increases overall economic efficiency. At low levels of government spending, an increase in the tax rate raises the growth rate since the outlays (e.g., for infrastructure, education, public health, protection of property) are considered to be productive (Scully 2003). However, whereas the first euros spent have huge marginal effects, the next euros have smaller effects. For example, once a country possesses primary roads, the positive effects of secondary roads are smaller. In addition, as higher taxes are needed to finance government, distortions usually become more prevalent. Agents change their behavior in order to escape taxes. Public choice theory also predicts that the government officials become increasingly self-interested and not benevolent (see Mueller 2003 for an overview). Therefore, the curve has a concave shape due to decreasing marginal returns: a proportional increase in spending and taxation yields a less than proportional increase in economic growth. But thanks to positive externalities, an additional percentage of tax burden still creates higher economic efficiency (i.e., a positive slope).

At some point, the marginal benefits from increased government spending become zero. With a tax burden of $T^{*}$, the government induces the highest possible rate of economic growth. Beyond $T^{*}$, government spending is more oriented towards non-productive spending (e.g., transfers and subsidies). An increase in the tax rate then lowers the growth rate of the economy. In contrast to what has come before, the additional resources claimed by the government come at the cost of private projects with higher returns.

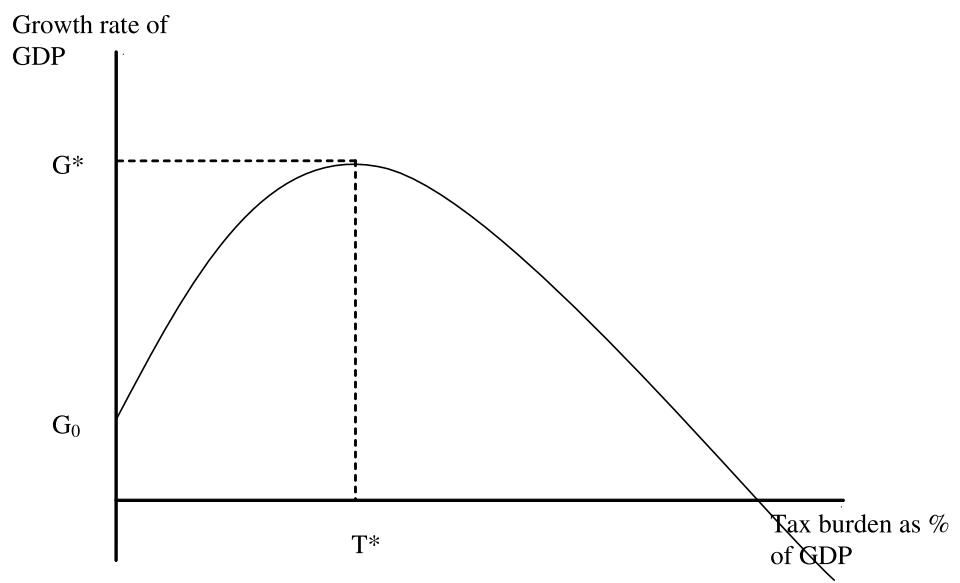

Fig. 3 Armey curve 


\subsection{Estimation of the optimal government size}

The empirical literature provides several attempts to estimate the optimal level of the public sector. We mention some studies. Based on a model of endogenous growth, Barro (1990) finds the growth maximizing tax rate to be $25.1 \%$. However, the standard error of the coefficient is so large that confidence in the estimate is quite small. Chao and Grubel (1998) place the maximum of the Armey curve for Canada at 34\% of GDP. Pevcin (2004) suggests that the Armey curve for 12 European countries peaks when government spending is between $36.6 \%$ and $42.1 \%$ of GDP. Scully (1994) estimated a curve similar to the Armey curve. His model yields an optimal tax burden of $19.3 \%$ of GDP for the United States and 23\% for New Zealand. According to Branson and Lovell (2001), New Zealand's growth maximizing tax burden is $22.5 \%$, far below the observed tax burden of $28 \%$. Afonso et al. (2006) calculate that countries with lean public sectors and with public expenditure ratios of about $30 \%$ of GDP tend to be the most efficient countries in terms of public performance. As we show below, our results are somewhat similar, in that we estimate the average optimal size for the OECD countries to be around $40 \%$ of GDP with a standard deviation of $5 \%$.

\subsection{Drawbacks of a parametric estimation}

Although the Armey curve represents an attractive conceptual framework, it suffers from a few drawbacks which make an empirical estimation of the curve rather inadequate. Some authors (e.g., Pevcin 2004) estimate the Armey curve by using a panel dataset in which the space and time dimension are disregarded. Measuring the optimum in this way assumes that all countries have the same $G_{0}$, as well as the same preferences and the same rate of decreasing marginal returns to government size (Slemrod et al. 1995). These assumptions seem unrealistic. Moreover, the social cost of raising revenues, as well as their social benefits, can be expected to vary among countries due to differences in the effectiveness of budgetary institutions and political economy factors. In some countries, for example, citizens favor redistributive policies, while in others they do not (Gupta et al. 2001).

If the Armey curve is estimated by country specific time series as in, e.g., Scully (2001), correlation is confused with causation. During periods of more robust economic growth, as in the 1950s and 1960s, government involvement was rather modest. Governments enlarged their outlays in the 1970s and 1990s when economic growth slowed down. However, this negative correlation does not necessarily mean causation. On the one hand, economic growth is subject to many exogenous factors (see, e.g., Crafts and Toniolo 1996); on the other hand, government involvement is the result of the aggregation of social preferences in society, which varies with the voting rules in place. Estimations such as those by Scully (2001) do not take these effects into account.

In addition, parametric models assume a priori a particular functional form on the dataset, which is difficult to justify. We suggest an alternative exploration by estimating the optimal tax burden by use of the non-parametric 'Data Envelopment Analysis' (DEA). This procedure allows us to compare governments and to benchmark their long term achievements. We will further correct by entering control variables, such as the openness of a country or preferences about government involvement in the economy (see infra). In this paper, we follow a top-down approach as explained in Slemrod et al. (1995). Top-down studies investigate the overall association between government involvement and economic growth. They contrast with bottom-up studies which estimate costs country by country, program by program and tax by tax. 


\section{Measuring government size with DEA}

\subsection{Measuring with DEA}

Data envelopment analysis (DEA) assesses the relative efficiency of decision making units (DMUs). The original model with constant returns to scale was proposed by Charnes, Cooper and Rhodes (CCR) (1978) and later extended by Banker, Charnes and Cooper (BCC) (1984) to variable returns to scale. The DEA approach defines a non-parametric frontier which serves as a benchmark for efficiency measures. The frontier is constructed as the piecewise linear combination of the efficient DMUs in the sample.

We consider the input-oriented model which searches for the minimal inputs needed to produce given outputs. The efficiency of a DMU is obtained as the maximum of the ratio of the weighted sum of its outputs to the weighted sum of its inputs, subject to the condition that this ratio for any DMU does not exceed 1. This condition means that no DMU can operate beyond the efficiency frontier. We further assume non-negative weights. If there are $m$ inputs $x_{i}, s$ outputs $y_{r}$ and $n$ DMUs (indexed by $j \varepsilon\{1,2, \ldots, n\}$ ), we state the BCC-problem as a simple linear programming formulation:

$$
\theta_{k}(x, y)=\left\{\theta \mid \theta x_{o} \geq \sum_{i=1}^{n} \gamma_{i} x_{i} ; y_{o} \leq \sum_{i=1}^{n} \gamma_{i} y_{i} ; \gamma_{i} \geq 0 ; \sum_{i=1}^{n} \gamma_{i}=1 ; i=1, \ldots, n\right\} .
$$

The inputs and outputs, labelled with a $i$ subscript, are the inputs and outputs of $D M U_{i}$ whose efficiency is being evaluated. The problem needs to be solved for every DMU. The technical efficiency score of $D M U_{i}$ is defined as the value of $\theta_{i}$. If $\theta_{i}$ equals 1 , the DMU is relatively efficient. If $\theta_{i}$ is less than 1 , it could produce, given its inputs, $\left(1-\theta_{i}\right)$ percent more outputs. We consider $\theta_{i}$ as a gross efficiency measure which we will further correct for control variables in order to obtain an adjusted net efficiency measure.

Consider the case where there is only one input variable in an input-oriented model. Multiplying the efficiency score $\theta_{i}$ by the only input value, we obtain the targeted input value. This targeted input value indicates the optimal input for the DMU, given its output. We compute the optimal size of the government by the use of this optimal target value.

\subsection{Advantages of DEA}

To our best knowledge, the optimum of the Armey curve has been estimated only by the use of parametric methods. In this contribution, we apply an input-oriented DEA model to the problem (i.e., minimization of the inputs for a given amount of outputs). Although one of the advantages of DEA is the use of multiple inputs and outputs, we compute the model only for one input and one output variable. The tax burden is used as the input variable, and GDP growth as the output variable. This is consistent with the idea behind the Armey curve: for a given GDP growth rate, what is the optimal level of tax burden? By the use of DEA, we calculate for every country an optimal government size relative to the observed performances of the other countries in the dataset. In other words, we benchmark the governments by relating a country's economic growth to the size of its government. Since DEA is a nonparametric estimation procedure, we do not need any a priori assumption about the shape of the production function, as is required in the literature estimating an inverted U-shape. Moreover, in a second step, we will take into account control variables (e.g., openness of the country) and preferences (e.g., redistribution towards families). 
The analysis covers OECD economies. Studying only OECD countries offers several advantages (see, e.g., Afonso and Furceri 2008). Firstly, data quality and comparability are of higher standards. Comparability is the more important due to the relative nature of the DEA technique. Secondly, data from OECD and non-OECD countries do not share a common set of coefficients in growth regressions (Grier and Tullock 1989). As such, it is difficult to pool these data. Finally, and related to the previous point, the economic structures in emerging OECD countries differ from those in mature economies. Therefore, we consider a sample of 23 reasonably comparable OECD countries. We borrow the data from the OECD statistical databases and evaluate the year 1999 (due to data constraints for family size, see infra). Nevertheless, we experimented with other years as well. As mentioned earlier, the output variable is GDP growth. ${ }^{1}$ Gross Domestic Product (GDP) is preferred to Gross National Product (GNP) as GDP yields a better correlation with the economic activity within a country. The degree of government involvement is measured by the level of general government spending (total outlays). General government spending is the sum of the spendings by the central, state and local government, as well as social security spendings.

The input-oriented efficiency scores are presented in the first column of Table 1. We learn from this exercise that Ireland and the United States allocate the taxes levied most efficiently. For a given GDP growth, their governments need the smallest tax absorption. The Swedish and Danish governments spend according to the gross efficiency scores the collected taxes in the least efficient way in order to push GDP. The average gross efficiency score is 0.75 . This means that, if governments would perform efficiently (i.e., as the US and Irish governments), they would only need $75 \%$ of the current taxation level.

\section{Correction for exogenous influences}

To improve the comparability of the sample, we make corrections for preferences and some other control variables. By the use of a specially designed econometric procedure, we correct the gross efficiency scores to obtain net efficiency values. We first introduce and explore the concept of the anorexia family.

\subsection{The anorexia family}

Family size in OECD countries steadily decreased during the last few decades. Whereas an average family consisted of 2.8 members in 1988, eleven years later a typical family has only 2.5 members (see Fig. 4). One could say that the anorexia family emerges. The question remains as to what extent this decline in family size reflects government involvement. Empirically, we find a strong negative correlation $(-0.80)$ between family size and overall government taxes measured as a percentage of GDP and between family size and government spending (-0.55) (see Fig. 5 for 1999 data).

On the one hand, the anorexia family invites the government to take up more tasks. Whereas before, for instance, families themselves looked after their younger and older members, daycare centers and rest homes supported by the government often fulfill that requirement nowadays. Several tasks which formerly were family responsibilities are nowadays assigned to the welfare state. On the other hand, thanks to extended government involvement,

\footnotetext{
${ }^{1}$ In order to filter out the economic cycles from the raw data, we take the arithmetic mean of real GDP growth for the period 1988-2004. The variable thus obtained reads as the long-run GDP growth.
} 
Table 1 Optimal government size with GDP growth

\begin{tabular}{|c|c|c|c|c|c|c|}
\hline & $\begin{array}{l}\text { Gross } \\
\text { efficiency } \\
\operatorname{score}\left(\theta_{i}^{a d j^{0}}\right) \\
(1)\end{array}$ & $\begin{array}{l}\text { Residuals } \\
\text { Tobit } \\
\epsilon_{i} \\
(2)\end{array}$ & $\begin{array}{l}\text { Net } \\
\text { efficiency } \\
\text { score }\left(\theta_{i}^{a d j^{3}}\right) \\
\text { (3) }\end{array}$ & $\begin{array}{l}\text { Size } \\
\text { public } \\
\text { sector } \\
(4)\end{array}$ & $\begin{array}{l}\text { Long run } \\
\text { optimal } \\
\text { size } \\
(5)=(4) *(3)\end{array}$ & $\begin{array}{l}\text { Change in } \\
\text { long run } \\
\text { size } \\
(5)-(4)\end{array}$ \\
\hline Australia & 0.921 & 0.052 & 0.972 & 37.947 & 36.883 & -1.063 \\
\hline Austria & 0.606 & -0.008 & 0.912 & 50.893 & 46.418 & -4.475 \\
\hline Belgium & 0.642 & -0.007 & 0.913 & 49.114 & 44.852 & -4.262 \\
\hline Canada & 0.795 & -0.004 & 0.917 & 44.298 & 40.611 & -3.687 \\
\hline Denmark & 0.577 & -0.001 & 0.919 & 57.233 & 52.596 & -4.637 \\
\hline Finland & 0.643 & 0.017 & 0.938 & 53.899 & 50.555 & -3.344 \\
\hline France & 0.612 & -0.036 & 0.884 & 50.885 & 44.997 & -5.888 \\
\hline Germany & 0.657 & 0.000 & 0.920 & 46.723 & 42.993 & -3.730 \\
\hline Greece & 0.701 & -0.078 & 0.842 & 46.035 & 38.778 & -7.257 \\
\hline Iceland & 0.771 & -0.045 & 0.876 & 45.474 & 39.819 & -5.656 \\
\hline Ireland & 1.000 & 0.000 & 0.920 & 36.465 & 33.565 & -2.900 \\
\hline Italy & 0.649 & -0.138 & 0.783 & 47.140 & 36.898 & -10.242 \\
\hline Japan & 0.839 & 0.035 & 0.955 & 30.569 & 29.205 & -1.364 \\
\hline Luxembourg & 0.785 & 0.000 & 0.920 & 45.055 & 41.472 & -3.583 \\
\hline Netherlands & 0.705 & 0.008 & 0.929 & 45.638 & 42.385 & -3.253 \\
\hline New Zealand & 0.804 & 0.137 & 1.057 & 40.075 & 42.376 & 2.301 \\
\hline Norway & 0.678 & 0.022 & 0.943 & 54.311 & 51.194 & -3.117 \\
\hline Portugal & 0.741 & 0.036 & 0.957 & 40.933 & 39.157 & -1.776 \\
\hline Spain & 0.798 & -0.003 & 0.918 & 38.267 & 35.125 & -3.141 \\
\hline Sweden & 0.557 & -0.046 & 0.874 & 62.665 & 54.784 & -7.881 \\
\hline Switzerland & 0.876 & 0.000 & 0.920 & 34.656 & 31.900 & -2.756 \\
\hline United Kingdom & 0.821 & 0.050 & 0.971 & 40.734 & 39.537 & -1.198 \\
\hline United States & 1.000 & -0.010 & 0.911 & 35.162 & 32.017 & -3.145 \\
\hline Average & 0.747 & & 0.920 & 44.964 & 41.222 & -3.741 \\
\hline St. Deviation & 0.126 & & 0.051 & 7.870 & 6.826 & 2.563 \\
\hline
\end{tabular}

families could become smaller. Governments provide, for instance, pension allowances such that children are no longer the only safeguards for retired parents. ${ }^{2}$

Although we find a strong correlation, we do not know the direction of the causality. In further research, this causality should be carefully examined by Instrumental Variables (IV) techniques. ${ }^{3}$ To present a flavor of the correlation between the family size and the government size, by use of an ordinary least squares estimation, we test the hypothesis that, for 23 OECD-countries, a smaller family size yields a larger government. The results are presented in Table 2. Family size alone can explain $30.5 \%$ of the variation in taxation

\footnotetext{
${ }^{2}$ Note that when government taxes are considered as a proxy for the government size, the causation could be influenced by the design of the tax system. For a specific tax system, a larger family size could reduce government revenues.

${ }^{3}$ In the current research, we do not examine causality formally as (1) the appropriate techniques are not available in the non-parametric DEA and as (2) selecting the appropriate IVs is an intricate issue.
} 


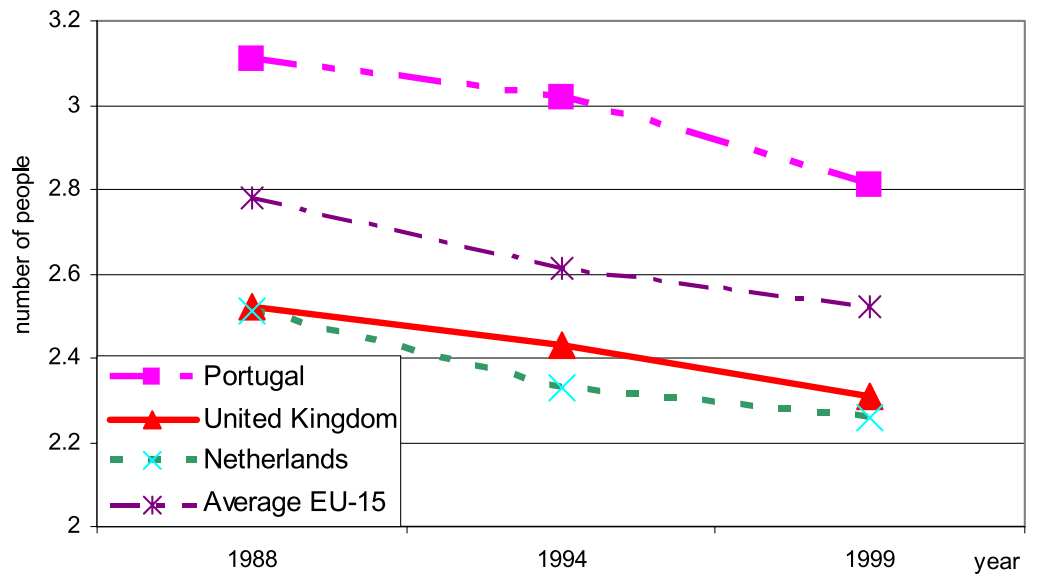

Fig. 4 Family size 1988-1999

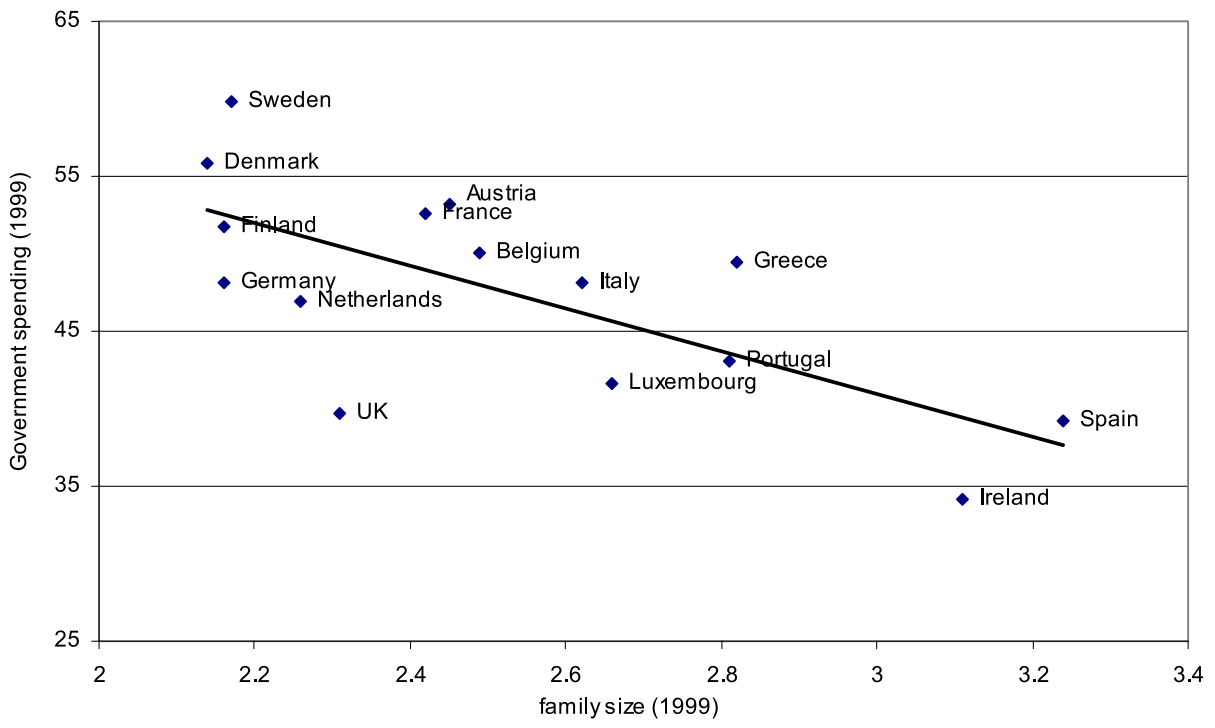

Fig. 5 The anorexia family and government spending

levels. We also checked whether the results remain robust if we add per capita GDP as an explanatory variable.

There exists a large and growing public finance literature on the relationship between government involvement and family size. A large part of the literature focuses on the link between fertility, growth and government size. This branch is based on the inspiring paper of Galor and Weil (1996). Another branch of the literature discusses the role of family size in the design of optimal income taxation (e.g., Cremer et al. 2003). However, to our best knowledge the literature does not provide a model which specifies the relationship between family size and the size of the government. 
Table 2 Relationship government size-family size

*** Denotes significance at $1 \%$ level

Table 3 Relationship social expenditures-family size

*** Denotes significance at $1 \%$ level

\begin{tabular}{lcc}
$\begin{array}{l}\text { Dependent variable: logarithm of average taxes levied by general } \\
\text { government } \\
\text { Variable }\end{array}$ & Coefficient & Std. error \\
\hline Constant & $4.6027^{* * *}$ & 0.2744 \\
Family size & $-0.3277^{* * *}$ & 0.1080 \\
$R$-squared & 0.3049 & \\
\hline
\end{tabular}

Dependent variable: logarithm of total social expenditures

\begin{tabular}{lcc} 
Variable & Coefficient & Std. error \\
\hline Constant & $4.3218^{* * *}$ & 0.3424 \\
Family size & $-0.4889^{* * *}$ & 0.1347 \\
$R$-squared & 0.3854 & \\
\hline
\end{tabular}

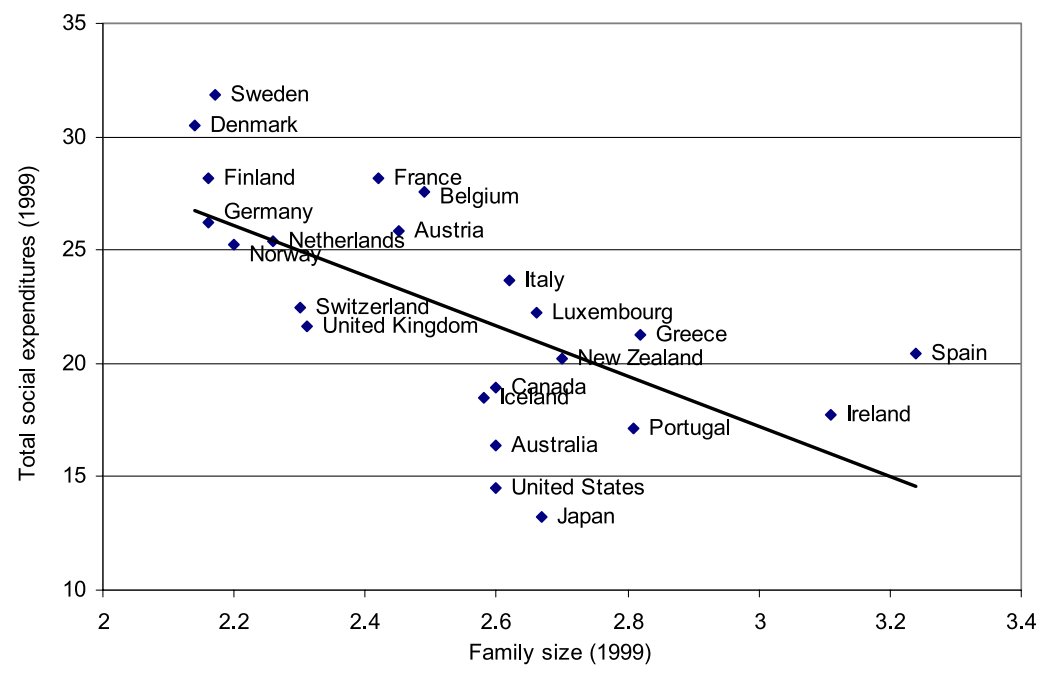

Fig. 6 The anorexia family and total social expenditures

In the remainder of this section, we consider family size to represent an implicit preference for the extent of government involvement. Societies which prefer a larger government involvement (e.g., Denmark with general government spending equal to $52.5 \%$ of GDP in 1999), have on average smaller families (i.e., Denmark counts only 2.14 members in 1999). Due to the unknown causality, the reverse also is true: societies with lean public sectors (e.g., Spain with $38.3 \%$ of GDP), have on average bigger families (i.e., Spain counts 3.24 family members). If we consider total 'social' expenditures, which are measured as the sum of the resources spent for families, disabled persons, the unemployed, elderly people and sick persons, as an explicit measure for government involvement, we find a significant negative correlation $(-0.65)$ between explicit and implicit preferences. Family size can explain $38.5 \%$ of the variation in total social expenditures (see Table 3 and Fig. 6). 


\subsection{Other control variables}

The countries in the sample differ in several aspects. First of all, different countries have different tastes and preferences about the optimal size of government. We capture preferences for the extent of government involvement by the average family size. Countries with lean families prefer larger governments, as argued in the previous section.

Secondly, we correct for the degree of countries' openness to trade. Open countries are more subject to external shocks and therefore need a larger public sector to accomplish a stabilizing role (Roderik 1996). We measure the degree of openness by computing the sum of exports and imports as a percentage of GDP. Afonso et al. (2006) remark that exports also can act as a proxy for the degree of international competition in labor and capital markets, and that greater competitiveness would penalize public inefficiency disproportionately. If the penalizing effect of Afonso et al. (2006) dominates, we expect a positive sign in the correction; if Roderik's stabilizing requirement dominates, we expect a negative sign.

A third correction measure is GDP per capita. It captures the large income elasticity (exceeding one) with respect to governmental services as suggested by Wagner (1877). He stated that richer economies prefer larger public sectors. In addition, GDP per capita is also a measure of the income of the median voter ${ }^{4}$ (although median income is more usual), who is an important actor in the public choice literature (starting from Tullock 1972; Borcherding and Deacon 1972).

Fourthly, we include the capital stock of a country. This variable aims to proxy the physical capital stock which stimulates the efficient production of (public and private) goods and services (Afonso et al. 2006).

Finally, we include some traditional variables to explain government involvement: country size (expressed as total population), population density and urbanization (proxied by the share of national population in the $10 \%$ of regions with the largest populations).

In order to compute the adjusted net efficiency score for each DMU, we econometrically explore these factors which are likely to influence productive efficiency. The left-hand variable is the gross efficiency score, while the right-hand variables are the correction factors. Since the gross efficiency scores are right-censored (no values above 1), we have to estimate by a Tobit model. The regression residuals from the Tobit model indicate the portion of the efficiency that remains unexplained after correcting for the control variables (Tupper and Resende 2004). Since the residuals alternate in sign, whereas a proper efficiency measure should possess a one-sided distribution, we use the procedure of Gasparini and Ramos (2003), which allows us to generate adjusted DEA scores that are confined within the $[0,1]$ interval:

$$
\theta_{i}^{a d j}=\epsilon_{i}+\left(1-\max _{j=1, \ldots, n} \epsilon_{j}\right)
$$

where $\theta_{i}^{a d j}$ denotes the adjusted efficiency score for $D M U_{i}$, and $\epsilon_{i}$ stands for the residual for each $D M U_{i}$ obtained from the Tobit estimation.

However, we consider this procedure as 'too severe'. Some governments could be 'inefficient' simply because they are too small. Those governments could, by increasing the tax burden, obtain a larger GDP growth. The adjusted efficiency score as obtained by (2) fails to detect those inefficient governments. Therefore, we extend the procedure of Gasparini and Ramos (2003) to a more general correction mechanism. Our suggestion is to consider

\footnotetext{
${ }^{4}$ Indeed, thanks to the law of large numbers we approximate a normal distribution such that the median value converges to the mean value.
} 
not only the largest residual, but an average of the $w$ largest residuals. Hence, we sort the residuals $\epsilon_{i}$ in order of magnitude and compute:

$$
\theta_{i}^{a d j^{w}}=\epsilon_{i}+\left(1-\frac{1}{w} \sum_{j=1}^{w} \epsilon_{j}\right) .
$$

Obviously, the relative rigour of the correction depends on the number $w$ by which the residuals are corrected. The larger is $w$, the less severe is the correction and, hence, the larger is the average optimal public sector. As we do not know the proper value of $w$, we further perform a sensitivity analysis.

\subsection{Sizing the government}

The results of the estimation are given in Table 1. The left column in the table represents the uncorrected gross efficiency scores. By estimating a Tobit regression, we correct the gross efficiency scores. The Tobit estimation is presented in Table 4. Family size, openness of the economy, country size, population density and urbanization have a statistically significant effect on the efficiency of the DEA model. As capital stock has a very insignificant effect, we removed it from the results. Family size has the expected positive effect on gross efficiency. The larger the average family, the higher the gross efficiency. Hence, countries with larger average family size (and thus preferences for less government involvement), can create a given GDP growth with fewer government spendings. Since larger exports decrease efficiency, Roderik's stabilizing effect emerges. GDP per capita shows a positive but insignificant effect on efficiency: the richer the country, the higher the gross efficiency. Both country size, population density and urbanization influence the gross efficiency scores positively.

As also the size of the effect is of importance, we present in Fig. 7 the effect on the mean of each of the significant variables. We observe that the effect of the household size has the largest influence on efficiency. Urbanization, population density and population clearly have smaller effects on the mean.

Since we are primarily interested in the residuals which we obtain from the Tobit regression, the finding whether a certain variable has a significant impact on the efficiency score does not matter so much for our purpose. The residuals are reproduced in the second column of Table 1. From the residuals, we compute the net efficiency scores by use of (3) with $w$ arbitrarily set to, e.g., 3 (later on, we perform a sensitivity analysis). The optimal size is computed as the government size times the adjusted net efficiency score.

Table 4 Tobit estimation with GDP growth

\begin{tabular}{llcl}
\hline & & Coefficient & Std. error \\
\hline efficiency $=$ & Constant & $-3.551 \mathrm{E}-02$ & 0.157 \\
& Size household & $2.179 \mathrm{E}-01^{* * *}$ & 0.053 \\
& Openness & $-9.100 \mathrm{E}-04^{*}$ & 0.001 \\
GDP/cap. & $9.520 \mathrm{E}-06^{* * *}$ & 0.000 \\
& Population & $6.920 \mathrm{E}-10^{* * *}$ & 0.000 \\
& Population density & $6.290 \mathrm{E}-04^{* * *}$ & 0.000 \\
& Urbanization & $4.536 \mathrm{E}-03^{* * *}$ & 0.002 \\
\hline & $R$-squared & 0.844 \\
\hline
\end{tabular}

\footnotetext{
*** denotes efficiency at $1 \%$ level

** at $5 \%$ and

* at $10 \%$
} 


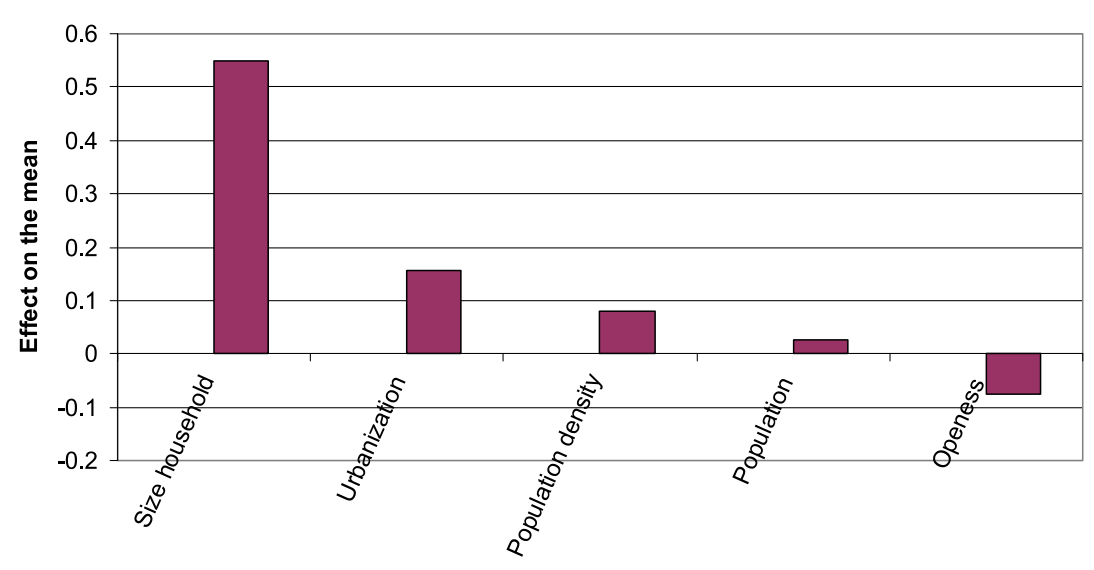

Fig. 7 Effect on the mean of the exploratory variables

From comparing the gross and the net efficiency scores, we learn that all countries, except for Ireland and the United States, gain from the correction for control variables. The efficiency scores of Denmark, Sweden and Austria increase the most, thanks to the correction for redistributive preferences. If we take control factors into account, the optimal average tax burden of the 23 OECD countries should amount to $41.22 \%$ of GDP. The public sector thus should on average decrease by 3.74 percentage points. Note that our results compare well with those in related literature (e.g., Chao and Grubel 1998 or Pevcin 2004). But the optimal government size differs considerably among countries. The largest decrease in tax burden should occur in Italy, with a fall of 10.24 percentage points. Also Sweden, Greece, Iceland and France should decrease the tax burden by more than 5 percentage points. In contrast, the tax burden in New Zealand should optimally increase by 2.30 percentage points to $42.37 \%$ of GDP.

In order to test the robustness of $w$ in determining the size of the optimal government involvement, we perform a sensitivity analysis. We compute for several values of $w$ the optimal tax burden. The results are presented in Table 5. Notice that, as $w$ increases, the optimal size of government rises as well. The difference between $\theta_{i}^{a d j^{1}}$ and $\theta_{i}^{a d j^{7}}$ amounts on average to 3.92 percentage points. However, some countries benefit more from generous weighting. At 5.45 percentage points, the difference between $\theta_{i}^{a d j^{1}}$ and $\theta_{i}^{a d j^{7}}$ is largest in Sweden. Sweden is followed by Denmark (a difference of 4.98), Norway (4.72) and Finland (4.69). These Scandinavian countries take most advantage of a more generous weighting of $w$. Japan (with 2.66) obtains the least gain from the weighting system.

However, even in a very generous model (i.e., $w$ equal to 7), most governments would have to decrease spending by 2.41 percentage points in order to obtain higher GDP growth. New Zealand again stands out: none of the models supply evidence that the tax burden should be lowered there. Australia and the United Kingdom optimally should increase the sizes of their governments when we set $w$ at 7 or higher.

\subsection{Public sector performance}

Economic growth is not the only objective a government can pursue. Musgrave (1959) defined three major tasks for the government: (1) allocative efficiency, (2) economic stability and (3) redistribution. Afonso et al. (2005) added to these main tasks four opportunity indicators: the quality of administration, education, health and public infrastructure. The last 
Table 5 Sensitivity analysis

\begin{tabular}{|c|c|c|c|c|c|c|c|c|}
\hline & Actual size & $\theta_{i}^{a d j^{1}}$ & $\theta_{i}^{a d j^{2}}$ & $\theta_{i}^{a d j^{3}}$ & $\theta_{i}^{a d j^{4}}$ & $\theta_{i}^{a d j^{5}}$ & $\theta_{i}^{a d j^{6}}$ & $\theta_{i}^{a d j^{7}}$ \\
\hline Australia & 37.947 & 34.704 & 36.326 & 36.883 & 37.295 & 37.551 & 37.803 & 38.008 \\
\hline Austria & 50.893 & 43.496 & 45.670 & 46.418 & 46.970 & 47.314 & 47.652 & 47.927 \\
\hline Belgium & 49.114 & 42.031 & 44.130 & 44.852 & 45.384 & 45.716 & 46.042 & 46.307 \\
\hline Canada & 44.298 & 38.067 & 39.960 & 40.611 & 41.092 & 41.391 & 41.685 & 41.924 \\
\hline Denmark & 57.233 & 49.310 & 51.755 & 52.596 & 53.217 & 53.604 & 53.983 & 54.293 \\
\hline Finland & 53.899 & 47.460 & 49.763 & 50.555 & 51.140 & 51.504 & 51.861 & 52.152 \\
\hline France & 50.885 & 42.075 & 44.249 & 44.997 & 45.549 & 45.893 & 46.230 & 46.505 \\
\hline Germany & 46.723 & 40.309 & 42.306 & 42.993 & 43.499 & 43.815 & 44.125 & 44.377 \\
\hline Greece & 46.035 & 36.135 & 38.102 & 38.778 & 39.278 & 39.589 & 39.894 & 40.143 \\
\hline Iceland & 45.474 & 37.207 & 39.150 & 39.819 & 40.312 & 40.619 & 40.921 & 41.166 \\
\hline Ireland & 36.465 & 31.471 & 33.029 & 33.565 & 33.961 & 34.207 & 34.449 & 34.646 \\
\hline Italy & 47.140 & 34.191 & 36.205 & 36.898 & 37.409 & 37.728 & 38.040 & 38.295 \\
\hline Japan & 30.569 & 27.449 & 28.755 & 29.205 & 29.536 & 29.743 & 29.946 & 30.111 \\
\hline Luxembourg & 45.055 & 38.884 & 40.809 & 41.472 & 41.960 & 42.265 & 42.564 & 42.807 \\
\hline Netherlands & 45.638 & 39.764 & 41.714 & 42.385 & 42.880 & 43.189 & 43.491 & 43.738 \\
\hline New Zealand & 40.075 & 40.075 & 41.787 & 42.376 & 42.811 & 43.081 & 43.347 & 43.564 \\
\hline Norway & 54.311 & 48.075 & 50.395 & 51.194 & 51.783 & 52.150 & 52.510 & 52.803 \\
\hline Portugal & 40.933 & 36.807 & 38.556 & 39.157 & 39.601 & 39.878 & 40.149 & 40.370 \\
\hline Spain & 38.267 & 32.928 & 34.563 & 35.125 & 35.540 & 35.799 & 36.053 & 36.259 \\
\hline Sweden & 62.665 & 51.185 & 53.863 & 54.784 & 55.464 & 55.887 & 56.303 & 56.641 \\
\hline Switzerland & 34.656 & 29.909 & 31.390 & 31.900 & 32.275 & 32.510 & 32.739 & 32.927 \\
\hline United Kingdom & 40.734 & 37.197 & 38.938 & 39.537 & 39.979 & 40.254 & 40.524 & 40.744 \\
\hline United States & 35.162 & 29.997 & 31.500 & 32.017 & 32.398 & 32.636 & 32.869 & 33.059 \\
\hline Average & 44.964 & 38.640 & 40.561 & 41.222 & 41.710 & 42.014 & 42.312 & 42.555 \\
\hline Maximum & 62.665 & 51.185 & 53.863 & 54.784 & 55.464 & 55.887 & 56.303 & 56.641 \\
\hline Minimum & 30.569 & 27.449 & 28.755 & 29.205 & 29.536 & 29.743 & 29.946 & 30.111 \\
\hline St. Deviation & 7.870 & 6.398 & 6.716 & 6.826 & 6.907 & 6.957 & 7.007 & 7.047 \\
\hline
\end{tabular}

four indicators describe the rule of law and the promotion of equality and opportunity in the market place. Afonso et al. (2005) constructed the composite indicator 'Public Sector Performance' (PSP) by equal weighting of these seven sub-indicators.

We investigate whether the optimal size of the government changes if we use the PSPindicator in the first step of the DEA-model. In this setting, the government has to minimize spending, while fulfilling a whole set of public activities. In the DEA input-model, government spending remains the input, while PSP becomes the output variable. Once more we correct for implicit preferences (family size as proxy), openness, GDP per capita, country size, population density and urbanization. The results are given in Table 6.

Table 6, with PSP as output in the first step, differs slightly from Table 1 where GDP growth is the output in the initial DEA model. Whereas the average optimal size was $41.22 \%$, an extension to broader government tasks yields an optimal tax burden of $42.18 \%$. Again we compute the difference between the actual size and the long run optimum. The Italian public sector should reduce its resources the most. It should optimally decrease its spending by 9.22 percentage points. Sweden, Germany, France and Finland complete the top-five 
Table 6 Optimal government size with PSP

\begin{tabular}{|c|c|c|c|c|c|c|}
\hline & $\begin{array}{l}\text { Gross } \\
\text { efficiency } \\
\text { score }\left(\theta_{i}^{a d j^{0}}\right) \\
1\end{array}$ & $\begin{array}{l}\text { Residuals } \\
\text { Tobit } \\
\epsilon_{i} \\
2\end{array}$ & $\begin{array}{l}\text { Net } \\
\text { efficiency } \\
\text { score }\left(\theta_{i}^{a d j^{3}}\right) \\
3\end{array}$ & $\begin{array}{l}\text { Size } \\
\text { public } \\
\text { sector } \\
4\end{array}$ & $\begin{array}{l}\text { Long run } \\
\text { optimal } \\
\text { size } \\
5=4 * 3\end{array}$ & $\begin{array}{l}\text { Change in } \\
\text { long run } \\
\text { size } \\
5=4\end{array}$ \\
\hline Australia & 0.959 & 0.104 & 1.060 & 35.714 & 37.851 & 2.137 \\
\hline Austria & 0.606 & -0.042 & 0.914 & 50.222 & 45.894 & -4.328 \\
\hline Belgium & 0.642 & 0.038 & 0.994 & 47.593 & 47.303 & -0.290 \\
\hline Canada & 0.785 & -0.032 & 0.924 & 42.935 & 39.688 & -3.247 \\
\hline Denmark & 0.577 & 0.015 & 0.971 & 56.160 & 54.514 & -1.646 \\
\hline Finland & 0.643 & -0.037 & 0.919 & 54.501 & 50.092 & -4.409 \\
\hline France & 0.612 & -0.051 & 0.905 & 49.136 & 44.486 & -4.650 \\
\hline Germany & 0.657 & -0.067 & 0.889 & 44.779 & 39.808 & -4.971 \\
\hline Greece & 0.701 & -0.061 & 0.895 & 40.716 & 36.440 & -4.276 \\
\hline Iceland & 0.771 & 0.012 & 0.968 & 42.084 & 40.728 & -1.356 \\
\hline Ireland & 0.963 & 0.005 & 0.961 & 38.414 & 36.898 & -1.515 \\
\hline Italy & 0.649 & -0.160 & 0.796 & 45.290 & 36.070 & -9.220 \\
\hline Japan & 1.000 & 0.040 & 0.996 & 31.673 & 31.537 & -0.136 \\
\hline Luxembourg & 0.891 & 0.000 & 0.956 & 46.379 & 44.338 & -2.041 \\
\hline Netherlands & 0.705 & 0.023 & 0.979 & 46.675 & 45.693 & -0.983 \\
\hline New Zealand & 0.795 & 0.112 & 1.068 & 44.113 & 47.093 & 2.979 \\
\hline Norway & 0.678 & 0.116 & 1.072 & 55.491 & 59.466 & 3.975 \\
\hline Portugal & 0.741 & 0.008 & 0.964 & 38.871 & 37.463 & -1.407 \\
\hline Spain & 0.791 & -0.018 & 0.938 & 38.671 & 36.291 & -2.380 \\
\hline Sweden & 0.551 & -0.084 & 0.872 & 61.829 & 53.891 & -7.938 \\
\hline Switzerland & 0.876 & 0.000 & 0.956 & 33.253 & 31.789 & -1.463 \\
\hline United Kingdom & 0.821 & 0.054 & 1.010 & 40.166 & 40.580 & 0.413 \\
\hline United States & 1.000 & 0.003 & 0.959 & 33.537 & 32.173 & -1.364 \\
\hline Average & 0.757 & & 0.955 & 44.270 & 42.178 & -2.092 \\
\hline St. Deviation & 0.138 & & 0.064 & 7.866 & 7.534 & 3.118 \\
\hline
\end{tabular}

biggest declines. Norway, New Zealand, Australia and the United Kingdom should optimally enlarge their public sector to meet the PSP criteria even better.

The difference between the two models is largest for Norway. The optimal Norwegian spendings are 8.27 percentage points higher, if measured by PSP. The German government involvement should optimally be 3.18 percentage points smaller if measured by GDP growth as output variable in the first step. There is almost no difference between the two procedures for the United States ( 0.15 percentage points larger if measured by PSP as output in the first step) and Switzerland (0.11).

\section{Concluding remarks}

Government involvement expanded rapidly in the second part of the last century. Many economists insist on downsizing the government. Their arguments are based on the so-called 
Table 7 Tobit estimation with PSP

Where ${ }^{* * *}$ and ${ }^{* *}$ denote, respectively, significance at 1 and $5 \%$ level

\begin{tabular}{llcl}
\hline & & Coefficient & Std. error \\
\hline efficiency $=$ & Constant & $2.553 \mathrm{E}-01$ & 0.163 \\
& Size household & $9.142 \mathrm{E}-02$ & 0.064 \\
& Openness & $-9.640 \mathrm{E}-04$ & 0.001 \\
GDP/cap. & $5.270 \mathrm{E}-06^{* * *}$ & 0.000 \\
& Population & $1.110 \mathrm{E}-09^{* *}$ & 0.000 \\
Population density & $4.820 \mathrm{E}-04^{* *}$ & 0.000 \\
& Urbanization & $5.956 \mathrm{E}-03^{* * *}$ & 0.002 \\
\hline & $R$-squared & 0.763 & \\
\hline
\end{tabular}

'Armey curve'. We indicate that these estimates rely on unrealistic assumptions, the ignorance of preferences and a confusion of correlation with causation. We find a strong negative correlation between family size and overall government size. On the one hand, the anorexia family forces the government to take up more tasks. On the other hand, as government involvement expands, families could shrink.

We estimate by the use of a non-parametric 'Data Envelopment Analysis' (DEA) the gross efficiency of government spendings (1999 data). In a second stage, these gross-scores are corrected by linking them to classic control variables, such as initial per capita income (Wagner 1877), degree of openness (Roderik 1996), country size, population density and urbanization. We introduce family size as a novel explanatory variable. By the use of a generous correction mechanism, we compute the optimal size of the government. The optimal average government involvement in the 23 OECD countries amounts to $41.22 \%$ of GDP. This means that the public sector should on average decrease by 3.74 percentage points; the largest decrease should occur in Italy with a reduction of 10.24 percentage points, New Zealand should optimally increase its government involvement by 2.30 percentage points.

Borrowing the composite indicator 'Public Sector Performance' (PSP) of Afonso et al. (2005), we enlarge the objectives of government beyond economic growth. It appears that the average optimal tax burden slightly increases to $42.17 \%$. However, Italy and Sweden should still decrease their government involvement by more than 5 percentage points.

Acknowledgements We are grateful to Bart Capéau, Laurens Cherchye, Koen Decancq, Blanca Zuluaga, James Gibb, two anonymous referees, the Editor in Chief of Public Choice and participants at the OR48 Conference in Bath University for their helpful comments.

Open Access This article is distributed under the terms of the Creative Commons Attribution Noncommercial License which permits any noncommercial use, distribution, and reproduction in any medium, provided the original author(s) and source are credited.

\section{References}

Afonso, A., \& Furceri, D. (2008). Government size, composition, volatility and economic growth. ECB Working Paper Series 849 , p. 45.

Afonso, A., Schuknecht, L., \& Tanzi, V. (2005). Public sector efficiency: an international comparison. Public Choice, 123, 321-347.

Afonso, A., Schuknecht, L., \& Tanzi, V. (2006). Public sector efficiency, evidence for new EU member states and emerging markets. ECB Working Paper Series 581, p. 47.

Armey, D. (1995). The freedom revolution. Washington: Regnery.

Banker, R., Charnes, A., \& Cooper, W. (1984). Some models for estimating technological and scale inefficiencies in data envelopment analysis. Management Science, 30, 1078-1092. 
Barro, R. (1990). Government spending in a simple model of endogenous growth. Journal of Political Economy, 95(5), 103-125.

Baumol, W. (1967). Macroeconomics of unbalanced economic growth: the anatomy of the urban crisis. American Economic Review, 57, 415-426.

Borcherding, T. E., \& Deacon, R. T. (1972). The demand for the services of non-federal governments. American Economic Review, 62(5), 891-901.

Branson, J., \& Lovell, K. (2001). A growth maximizing tax structure for New Zealand. International Tax and Public Finance, 8, 129-146.

Buchanan, J., \& Tullock, G. (1977). The expanding public sector: Wagner squared. Public Choice, 31(1), $147-150$.

Chao, J., \& Grubel, H. (1998). Optimal levels of spending and taxation in Canada. In H. Grubel (Ed.), How to use the fiscal surplus: what is the optimal size of government? (pp. 53-68). Vancouver: Fraser Institute.

Charnes, A., Cooper, W., \& Rhodes, D. (1978). Measuring the efficiency of Decision Making Units. European Journal of Operational Research, 2, 429-444.

Crafts, N., \& Toniolo, G. (1996). Economic growth in Europe since 1945. Cambridge: Cambridge University Press.

Cremer, H., Dellis, A., \& Pestieau, P. (2003). Family size and optimal income taxation. Journal of Population Economics, 16, 37-54.

Galor, O., \& Weil, D. N. (1996). The gender gap, fertility, and growth. American Economic Review, 86, 374-387.

Gasparini, C., \& Ramos, F. (2003). Efetividade e eficiencia no ensino medio brasileiro. Economia Aplicada, 7, 389-411.

Grier, K., \& Tullock, G. (1989). An empirical analysis of cross-national economic growth: 1951-1980. Journal of Monetary Economics, 24, 259-276.

Gupta, S., Leruth, L., Mello, L., \& Chakravarti, S. (2001). Transition economies: How appropriate is the size and scope of Government? IMF working papers 55, p. 31.

Higgs, R. (1987). Crisis and Leviathan: Critical episodes in the growth of American government. Oxford: Oxford University Press.

Katsimi, M. (1998). Explaining the size of the public sector. Public Choice, 96, 117-144.

Lybeck, J., \& Henrekson, M. (1988). Explaining the growth of government (p. 396). Amsterdam: NorthHolland.

Meltzer, A., \& Richard, S. (1981). A rational theory of the size of government. Journal of Political Economy, 89, 914-925.

Meltzer, A., \& Richard, S. (1983). Tests of a rational theory of the size of government. Public Choice, 41, 403-418.

Mueller, D. C. (2003). Public Choice III (3rd edn.). Cambridge: Cambridge University Press.

Musgrave, R. (1959). The theory of public finance (pp. 161-385). New York: McGraw-Hill.

Niskanen, W. (1971). Bureaucracy and representative government. Chicago: Aldine and Atherton.

Pevcin, P. (2004). Does optimal size of government spending exist? Paper presented to the EGPA (European Group of Public Administration), 2004 Annual Conference, Ljubljana, p. 12.

Roderik, D. (1996). Why do more open economies have bigger governments? NBER working paper 5537, p. 36.

Scully, G. (1994). What is the optimal size of Government in the United States? NCPA policy report 188, p. 10.

Scully, W. (2001). Government expenditure and quality of life. Public Choice, 108, 123-145.

Scully, W. (2003). Optimal taxation, economic growth and income inequality. Public Choice, 115, $299-312$.

Slemrod, J., Gale, W., \& Easterly, W. (1995). What do cross-country studies teach about government involvement, prosperity and economic growth? Brookings Papers on Economic Activity, 2, 373-431.

Tullock, G. (1972). Book review: W.A. Niskanen, Bureaucracy and representative government. Public Choice, 12, 119-124.

Tupper, H., \& Resende, M. (2004). Efficiency and regulatory issues in the Brazilian water and sewage sector: an empirical study. Utilities Policy, 12, 29-40.

Wagner, A. (1877). Finanzwissenschaft. Leipzig: C.F. Winter. 